\section{AMERICAN SCIENCE}

THE chief signal officer of the U.S. army has been urging that physical observations of the sun be made, as of sun-spots, facula, protuberances, \&c., in reference to their supposed influence upon terrestrial meteorology, and has offered to publish the results monthly, or such of them as may be considered desirable by the observer, in the Monthly Weather Review. The United States Naval Observatory at Washington has already accepted this proposition, and it is considered very desirable that some other observatories in the east, and at least one on the western coast, co.operate in this undertaking.

Dr. C. A. White, palæontologist to the United States Geological and Geographical Survey of the Territories, has spent the past season making a critical study of the mesozoic and cainozoic strata of the great Rocky Mountain Region, and the results have tended to confirm in a remarkably clear manner the statement so often expressed by Dr. Hayden in his annual reports, that the entire series of deposits are consecutive from the Dakota group of cretaceous age below, to the Bridger group of tertiary age above., The sedimentation was evidently continuous through all the changes, from marine to brackish, and from brackish to fresh waters, that successively took place in that great region, although those changes in aqueous conditions produced corre. sponding changes in the then prevailing forms of invertebrate life.

The annulal report of the Board of Regents of the Smithsonian Institution for 1876 has been published, and, as usual, contains a great deal of matter interesting to men of science. The portions of the volume detailing the operations of the institution for 1876 is more especially occupied with an account of what was done in connection with the International Exhibition of 1876 , at Philadelphia, and especially of the very extensive and valuable presents made to the United States by the various foreign commissions, ard taken charge of by the institution, in accordance with the law of Congress. Reference is made to an application for an appropriation to erect an additional building to accommodate these objects, for which it is estimated that a floor space of 80,000 square feet will be required. Until this is done the col. lections in question must remain in their original packages, more than 4,000 in number, which are stored on four floors of a separate building, 50 by 100 feet, and filling them completely from floor to ceiling. As usual, the funds of the institution are reported as being in a favourable condition, the income not being exceeded by the expenditure, and an available balance even remaining in hand at the end of the fiscal year. The second part of the volume embraces biographical notices of Dom Pedro II., and also of Gay-Lussac, articles on the kinetic theories of gravitation, the revolutions of the crust of the earth, the asteroids between Mars and Jupiter, and a number of papers on ethnology and archæology. Of these the most important is by Prot. Mason on the Latimer collection of antiquities from Porto Rico, is which the more interesting objects of this unique series are figured. Other papers on ancient mines and mounds, implements of various kinds, \&c., are also contained in the volume.

We bave to record the death of Mr. Timothy Abbott Conrad, one of the oldest and most accomplished palrontologists of the United States. Mr. Conrad was born in I803, and commenced his investigations early in the century, begirining with the tertiary and creiaceous formations of the United States. In 1832 he commencer an illustrated work on the "Fossil Shells of the Tertiary Formations of the United States," which was, however, preceded in 1831 by his "American Marine Conchology." Most of his papers appeared in the American fournal of Science and Arts, and in the Proceedings and Memorrs of the Academy of Natural Sciences, Philadelphia. He also contributed largely to the reports of the various government exploring expeditions.

The Nation announces the death of Mr. John G. Anthony, for many years a devoted coadjutor of Agassiz in the Museum of Comparative Zoology at Cambricge, where he had charge of the conchological department. Long residence and extensive travel in the Ohio Valley had made him the first authority in the United States on fresh-water shells. He accompanied the Thayer expedition to Brazil, but sickness prevented him from taking part in it aiter its arrival. In addition to his special work Mr. Anthony always maintained an interest in Butany and horticulture. He was a native of Rhode Island, and was in the seventy-fourth year of his age.

Prof. Marsh makes the announcement of the interesting dis- covery of the remains of two species of fossil bison in the lower pliocene of Nebraska and Kansas. They were much larger than the existing bison, with more powerful horns.

\section{UNIVERSITY AND EDUCATIONAT INTELLIGENCE}

CAMBridgr. - The Vice-Chancellor, Dr. Atkinson, on resigning his office on November 3 (he has been re-slected) spoke of the progress of scientific teaching in the University. The efficiency of the University as a school of natural science has been greatly promoted, Dr. Atkinson stated, during the past year by the erection of the new buildings for the department of comparative anatomy and physiology. Although the whole building is not yet completed, many of the rooms are already in use, and the accommodation which is thus provided for both teachers and students will be of the greatest advantage. In connection with this subject Dr. Atkinson referred to Prof. Clerk Maxwell's announcement that His Grace the Chancellor has now completely equipped the Cavendish Laboratory with all the apparatus and instruments which the professor considers that a first-class institution of this kind ought to possess. This singular munificence, continued so steadily and ungrudgingly for such a number of years, is but one of the many proofs which His Grace is constantly giving of his unwearied care and concern for the welfare of the University.

The following gentlemen have been elected to fellowships at St. John's College :--Arthur Milnes Marshall, B.A., Senior in Natural Science Tripos, I874, and Donald M'Alister, B.A., Senior Wrangler and First Smith's Prizeman, 1877.

OXFORD, - AT a special meeting of the Town Council held at Oxford on Monday it was resolved to establish a first-class grammar school, the Corporation granting a site in the centre of the city of nearly an acre in extent, 4,000 . towards the building, and $\mathrm{rool}$. per annum towards its maintenance. There are to be fitty free scholarships tenable for three years, thirty of which are to be filled up from the public elementary schools.

London. - The Council of University, College, London, have appointed the Rev. T. G. Bonney, B.D., of St. John's College, Cambridge, Professor of Geology and Mineralogy for five years. ST. Andrews.-Mr. George Chrystal, B.A., Fellow and Lecturer of Corpus Christi College, Cambridge, has been appointed to succeed Prof. Fischer in the chair of mathematics.

Among the names likely to be brought forward by the students for the honorary and honourable post of rector of the University, that of Prof. Tyndall is mentioned.

\section{SCIENTIFIC SERIALS}

Morphologisches Fahrbuch, vol. iii. Part 3.-R. Bonnet, on the structure of, and circulation in, the gills of Acephala, pp. 45 , three plates. -C. Hasse, fossil vertebræ (the Squatinæ), two plates. - - R. Wiedersheim, the skull of Urodeles, pp. 97, five plates; a most valuable memoir on Menobranchus, Siren, Proteus, Amphiuma, Cryptobranchus, Menopoma, Salamandrina, Triton, Axolotl, Plethodon, Spelerpes, Ellipsoglrssa, Amblystoma. - M. Fürbringer, on the cephalic skeleton of Cephalopods.

Annalen der Physik und Chemie, No. 9.-On discontinuous liquid motions, by M. Oberbeck.-Explanation of Dufour's and Merget's experiments on the diffusion of vapours, by M. Kundt. -On the diffusion of liquids, by $M$. Johannisgänz,-On the internal friction of solid bodies, by M. Schmidt.-On the photoelectricity of fluorspar; by M. Hankel. - On the resistance of flames to the galvanic currert, by $M$. Hoppe.-On the electrochemical process at an aluminium anode, by M. Beetz. - Further experiments on galvanic expansion, by M. Exner.-Reply to Zöllner's objections against my electro-dynamic views, by $M$. Clausius. - On a mode of inference employed by Prof. Tait in the mechanical theory of heat, by M. Clausius.-On the sounding of air in pipes, by M. Ciamician.-The spectrum of nitrous and hyponitric acid, by M. Moser.-On optical illusion, by $\mathbf{M}$. Trappe.

Beiblätter zu den Annalen, \&c., No. 8.-On the equilibrium of a drop between two horizontal plates, by M. Bosscha.-On cylindrical sound-waves, by M. Grinwis.-Application of the galvanic current to investigation of the spheroioal state of some liquids, by M. Hesehus.- On the tenacity of copper and steel, by MM. Pisati and Saporita Ricca.-On the polymorphism of crystals, by M. Moutier. - The heat of solution of chlorine, bromine, and iodine compounds, by M. Thomsen.-New 